University of Nebraska - Lincoln

DigitalCommons@University of Nebraska - Lincoln

6-11-2016

Concentration Trends for Lead and Calcium-Normalized Lead in Fish Fillets from the Big River, a Mining-Contaminated Stream in Southeastern Missouri USA

Christopher J. Schmitt

Michael J. McKee

Follow this and additional works at: https://digitalcommons.unl.edu/usgsstaffpub

Part of the Geology Commons, Oceanography and Atmospheric Sciences and Meteorology Commons, Other Earth Sciences Commons, and the Other Environmental Sciences Commons

This Article is brought to you for free and open access by the US Geological Survey at DigitalCommons@University of Nebraska - Lincoln. It has been accepted for inclusion in USGS Staff -- Published Research by an authorized administrator of DigitalCommons@University of Nebraska - Lincoln. 


\title{
Concentration Trends for Lead and Calcium-Normalized Lead in Fish Fillets from the Big River, a Mining-Contaminated Stream in Southeastern Missouri USA
}

\author{
Christopher J. Schmitt ${ }^{1}$ (D) Michael J. McKee ${ }^{2}$
}

Received: 4 April 2016/Accepted: 6 June 2016/Published online: 11 June 2016

(C) Springer Science+Business Media New York (outside the USA) 2016

\begin{abstract}
Lead $(\mathrm{Pb})$ and calcium $(\mathrm{Ca})$ concentrations were measured in fillet samples of longear sunfish (Lepomis megalotis) and redhorse suckers (Moxostoma spp.) collected in 2005-2012 from the Big River, which drains a historical mining area in southeastern Missouri and where a consumption advisory is in effect due to elevated $\mathrm{Pb}$ concentrations in fish. Lead tends to accumulated in Ca-rich tissues such as bone and scale. Concentrations of $\mathrm{Pb}$ in fish muscle are typically low, but can become elevated in fillets from $\mathrm{Pb}$-contaminated sites depending in part on how much bone, scale, and skin is included in the sample. We used analysis-of-covariance to normalize $\mathrm{Pb}$ concentration to the geometric mean $\mathrm{Ca}$ concentration $(415 \mathrm{ug} / \mathrm{g}$ wet weight, ww), which reduced variation between taxa, sites, and years, as was the number of samples that exceeded Missouri consumption advisory threshold (300 ng/g ww). Concentrations of $\mathrm{Pb}$ in 2005-2012 were lower than in the past, especially after Ca-normalization, but the consumption advisory is still warranted because concentrations were $>300 \mathrm{ng} / \mathrm{g}$ ww in samples of both taxa from contaminated sites. For monitoring purposes, a simple linear regression model is proposed for estimating Ca-normalized $\mathrm{Pb}$ concentrations in fillets from $\mathrm{Pb}: \mathrm{Ca}$ molar ratios as a way of
\end{abstract}

Christopher J. Schmitt

cjschmitt@usgs.gov

Michael J. McKee

mike.mckee@mdc.gov.mo

1 Columbia Environmental Research Center, U.S. Geological Survey, 4200 New Haven Rd., Columbia, MO 65201, USA

2 Central Regional Office and Conservation Research Center, Missouri Department of Conservation, 3500 E. Gans Rd., Columbia, MO 65201, USA reducing the effects of differing preparation methods on fillet $\mathrm{Pb}$ variation.

Keywords Lead C Calcium · Mining - Longear sunfish · Redhorse suckers

The Big River (BR) and Flat River (FR), a tributary of the $\mathrm{BR}$, drain the Old Lead Belt (OLB), a historical lead $(\mathrm{Pb})$ and zinc mining area in Southeast Missouri USA (Fig. 1). About $180 \mathrm{~km}(81 \%)$ of the BR, from the upper end of the OLB downstream to its confluence with the Meramec River (MR), and most of the FR have been contaminated by $\mathrm{Pb}$ and other metals. The Big River Mine Tailings/St. Joe Minerals Site was added to the U.S. Environmental Protection Agency (USEPA) National Priorities List in 1992 (USEPA 2016a), and much of the FR and BR have been designated as "Impaired" due to elevated concentrations of $\mathrm{Pb}$ and other metals in sediments and fish (Missouri Department of Natural Resources 2010). There has been a "Do Not Consume" advisory due to elevated $\mathrm{Pb}$ in suckers (Catostomidae) since 1980 (Czarnezki 1985) that has been expanded to include longear sunfish (Lepomis megalotis; sunfish) and several other species [Missouri Department of Health and Senior Services (MDHSS) 2016]. Fillet $\mathrm{Pb}$ concentrations in these species often exceed $300 \mathrm{ng} / \mathrm{g}$ wet weight (ww), the concentration at which MDHSS may issue a consumption advisory when considered together with other factors and exposure pathways [U.S. Environmental Protection Agency (USEPA) 2016b]. Reduction of mine waste inputs to the BR and FR has been a focus of environmental remediation in the OLB and contaminated sediment removal is being considered (USEPA 2016a). One long-term goal of remediation is to reduce $\mathrm{Pb}$ concentrations in fish and rescind the consumption advisory. 


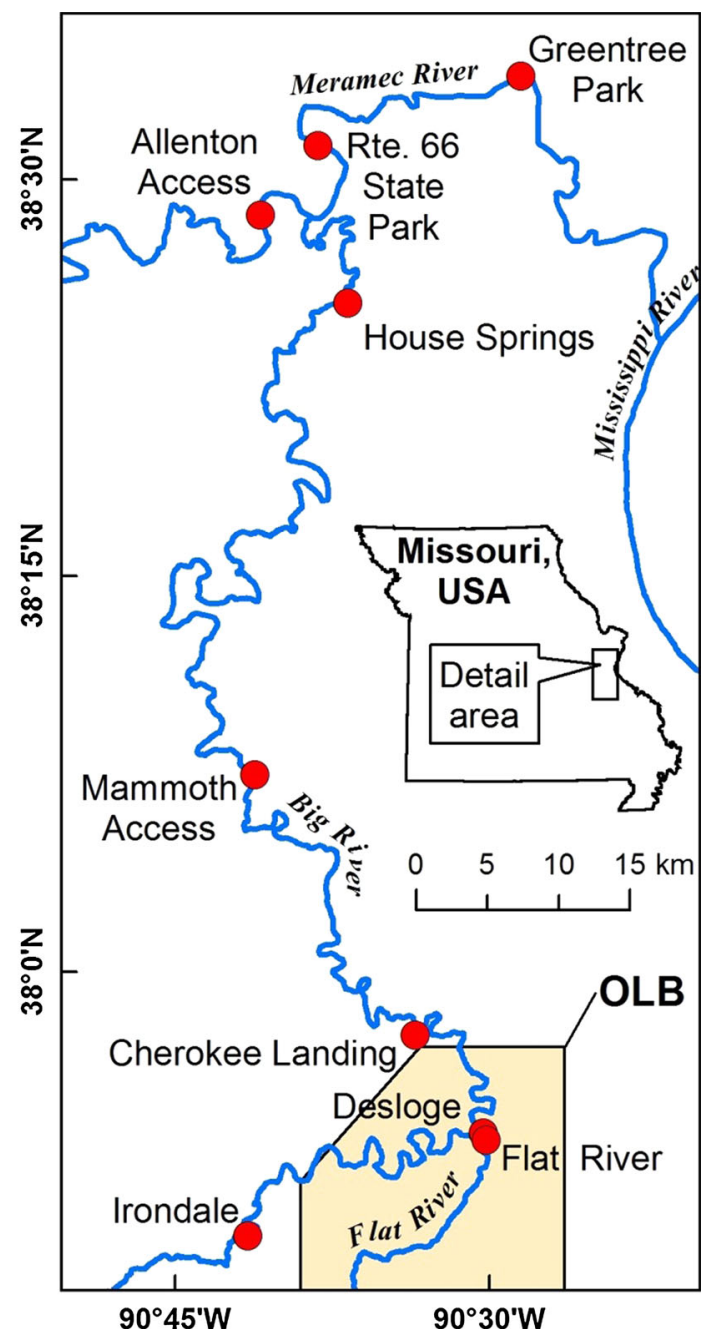

Fig. 1 Fish collection sites on the Big, Flat, and Meramec rivers in Missouri (OLB Old Lead Belt)

Much of the $\mathrm{Pb}$ in the parts of fish that people typically eat occurs as a trace contaminant of calcium $(\mathrm{Ca}$; Settle and Patterson 1980). As such, $\mathrm{Pb}$ tends to accumulate in $\mathrm{Ca}-$ rich tissues such as bone and scale. Mucus is also rich in $\mathrm{Ca}$, can bind waterborne metals, and may represent a pathway for metal excretion (Varanasi and Markey 1978). Muscle $\mathrm{Pb}$ concentrations are usually low, but previous studies have shown that the inclusion of bone or scale, contact with mucus, or external contamination during sample processing or analysis can substantially influence measured $\mathrm{Pb}$ concentrations and increase sample-to-sample variability (Settle and Patterson 1980; Wiener 1982; Schmitt and Finger 1987; Schmitt et al. 2007). A comparison of "clean" processed (scaled, de-boned, skinless; prepared in clean-room) and "normally" processed (scaled, skin-on, not de-boned; prepared streamside) fillets from BR fish showed that $\mathrm{Pb}$ concentrations in fillet samples from contaminated sites depend on how much material other than muscle is present, and that accounting for $\mathrm{Ca}$ can reduce the variance of fillet $\mathrm{Pb}$ by more than fourfold (Schmitt and Finger 1987).

Concentrations of $\mathrm{Pb}$ in $\mathrm{BR}$ fish have been monitored since the early 1980s (Czarnezki 1985; Schmitt and Finger 1987; Gale et al. 2004). However, determining whether fillet $\mathrm{Pb}$ concentrations have changed is difficult because fish collection and sample preparation procedures have differed among investigators and over time and $\mathrm{Ca}$ has not always been measured. Our objectives were therefore to determine whether $\mathrm{Pb}$ concentrations in $\mathrm{BR}$ fish have changed relative to historical concentrations after accounting for $\mathrm{Ca}$, and to establish a baseline for future monitoring with a uniform protocol that includes Ca normalization.

\section{Materials and Methods}

Fillet samples were collected as part of a statewide monitoring program. The number and locations of sites sampled each year vary, and composite samples are analyzed as a cost-saving measure. Fish for this study were collected by electrofishing in July-September 2005 and 2010-2012 at sites located on the BR upstream and within or downstream of the OLB, on the FR, and on the MR upstream and downstream from the confluence of the BR (Fig. 1; Table 1). The sampling objective was three 5-fish composites of sunfish and either black redhorse (Moxostoma duquesnii) or golden redhorse (M. erythrurum) at each site visit. Fish were grouped by species, measured (total length, $\mathrm{mm}$ ), weighed (g), and sorted into 5-fish composite samples in which the smallest fish was at least $75 \%$ as long as the largest [U.S. Environmental Protection Agency (USEPA) 2000]. Fish were killed by cervical dislocation, after which a skinless fillet was obtained from one side of each fish from the ribs to the caudal peduncle. The fillet was rinsed in distilled water and placed on aluminum foil. The five fillets constituting each composite sample were wrapped together in foil, placed in a labeled plastic bag, and stored on ice until transported to freezer for storage at $-20^{\circ} \mathrm{C}$. Workspace and equipment were replaced or rinsed with distilled water and isopropyl alcohol between each composite sample.

In the laboratory the frozen composite samples were partly thawed, chopped and minced, and freeze-dried. Moisture content was determined gravimetrically. The dried samples were pulverized to a fine powder, of which $0.25 \mathrm{~g}$ were digested with $6 \mathrm{~mL}$ of nitric acid and analyzed for $\mathrm{Pb}$ and $\mathrm{Ca}$ by inductively coupled plasma mass 
Table 1 Fish collection sites on the Big (B), Flat (F), and Meramec (M) rivers, 2005-2012 (OLB Old Lead Belt)

\begin{tabular}{|c|c|c|c|c|c|}
\hline River and site name & Site description & River km & UTM $X^{\mathrm{a}}$ & $\mathrm{UTM} \mathrm{Y}^{\mathrm{a}}$ & Year(s) sampled \\
\hline \multicolumn{6}{|l|}{ Meramec } \\
\hline Greentree Park & Below Big R. & $28.5^{\mathrm{b}}$ & 722377 & 4270844 & 2010 \\
\hline Allenton Access & Above Big R. & $5.5^{\mathrm{b}}$ & 704117 & 4261073 & 2011,2012 \\
\hline $\begin{array}{l}\text { Rte. } 66 \text { State Park } \\
\text { Big }\end{array}$ & Below Big R. & $7.2^{\mathrm{c}}$ & 708141 & 4265966 & 2011,2012 \\
\hline House Springs & Below OLB & $16.1^{\mathrm{d}}$ & 710245 & 4254900 & 2011,2012 \\
\hline Mammoth Access & Below OLB & $101^{\mathrm{d}}$ & 703747 & 4221830 & $2005,2010,2012$ \\
\hline Cherokee Landing & OLB & $145^{\mathrm{d}}$ & 714959 & 4203610 & 2010,2012 \\
\hline Flat R. above Big R. & OLB & $0.8^{\mathrm{c}}$ & 719928 & 4196240 & 2012 \\
\hline Desloge (Hwy. 67) & OLB & $166^{\mathrm{d}}$ & 719734 & 4196715 & 2012 \\
\hline Irondale (Hwy. U) & Above OLB & $204^{\mathrm{d}}$ & 703224 & 4189516 & 2010,2012 \\
\hline
\end{tabular}

spectrometry; Ca was analyzed as indicator of material other than muscle in the samples (Schmitt and Finger 1987; Schmitt et al. 2007, 2009). Analytical results in $\mathrm{ng} / \mathrm{g}(\mathrm{Pb})$ or $\mu \mathrm{g} / \mathrm{g}(\mathrm{Ca})$ dry weight $(\mathrm{dw})$ were converted to ww using each sample's moisture content.

Quality assurance (QA) measures included the analysis of certified reference materials, blanks, replicates, and fortified samples. Method detection limits were 1.6-2.9 $\mu \mathrm{g} /$ $\mathrm{g} \mathrm{dw}$ for $\mathrm{Ca}$ and 7.0-9.0 ng/g dw for $\mathrm{Pb}$, with method quantitation limits (MQLs) of $5.3-9.6 \mu \mathrm{g} / \mathrm{g} \mathrm{dw}$ and 23.0-30.0 ng/g dw, respectively. Concentrations in all samples exceeded MQLs and all quality-control results were considered acceptable. Five samples ( 2 redhorse, 3 sunfish) were analyzed in triplicate as part of the QA; relative standard deviations were $17 \%-26 \%$ for $\mathrm{Ca}$ and $26 \%-60 \%$ for $\mathrm{Pb}$, which are typical for these heterogeneously distributed elements. Including the five samples analyzed in triplicate, the dataset comprised 102 observations representing 92 composite fillet samples (14 black redhorse, 32 golden redhorse, and 46 sunfish). Raw data and details of the laboratory procedures and QA are available elsewhere (http://dx.doi.org/10.5066/F7125QR2; May et al. 2013).

Version 9.3 of the Statistical Analysis System (SAS Institute, Cary, NC USA) was used for statistical analyses. All data were $\log _{10}$-transformed. The molar ratio of $\mathrm{Pb}$ to $\mathrm{Ca}([\mathrm{Pb}] /[\mathrm{Ca}])$ was computed from measured concentrations and consensus atomic weights ( $\mathrm{Pb}$ 207.19, $\mathrm{Ca}$ $40.08) \times 10^{6}$. Concentrations of $\mathrm{Pb}$ and $\mathrm{Ca}$ in black and golden redhorse from the BR tend to be similar (Czarnezki 1985; Schmitt and Finger 1987), so these species were considered equivalent ("redhorse"). Preliminary statistical analyses included correlation, linear regression, and 3-way analysis-of-variance (ANOVA; SAS Proc GLM) with fixed effects of taxon $(\mathrm{T})$, collection site $(\mathrm{S})$, year $(\mathrm{Y})$, and their interactions on $\mathrm{Pb}$ and $\mathrm{Ca}$ concentrations and $[\mathrm{Pb}] /[\mathrm{Ca}]$. Results indicated that some analyses could be simplified by grouping sites as follows: Irondale (BR upstream of OLB); Desloge, FR, Cherokee Landing, and Mammoth Access (highly contaminated BR); House Springs (lower BR); and Rte. 66, Allenton, and Greentree (all MR). Results of these analyses also indicated that the $\mathrm{Y}$ main effect was not significant; site-year (S-Y) combinations were therefore considered rather than $\mathrm{S}$ and $\mathrm{Y}$ as separate factors. Neither $\mathrm{Pb}$ nor $\mathrm{Ca}$ was correlated with mean length or weight in either taxon, so length and weight were excluded from subsequent analyses.

The influence of $\mathrm{Ca}$ on spatial and temporal $\mathrm{Pb}$ patterns was assessed with analysis-of-covariance (ANCOVA; Hebert and Keenleyside 1995; Davis et al. 2013). The Ca concentrations were first centered (to geometric mean $=$ $0.0)$ by subtracting the overall geometric mean $(415 \mu \mathrm{g} / \mathrm{g}$ $\mathrm{ww}, \mathrm{n}=102$ ) from the concentration in each sample. Simple linear regressions of $\log _{10} \mathrm{~Pb}$ versus centered $\log _{10} \mathrm{Ca}$ for each taxon in each previously defined site group were then conducted, after which the Ca-normalized $\mathrm{Pb}$ concentration $(\mathrm{PbCa})$ in each sample was estimated as the sum of its residual and the appropriate intercept. $\log _{10}$-transformed $\mathrm{Pb}, \mathrm{Ca},[\mathrm{Pb}] /[\mathrm{Ca}]$ and $\mathrm{PbCa}$ were analyzed with a general linear model (SAS Proc GLM) with S-Y, T, and S-Y*T interaction as fixed effects; and samples within $\mathrm{S}-\mathrm{Y}$ and $\mathrm{T}$ as a random nested effect against which the fixed effects and interaction were evaluated. The $p$ values for $\mathrm{PbCa}$ were corrected for the degrees-of-freedom $(n=8)$ used in the regressions. Differences among S-Y means were evaluated with Tukey's 
test. Greentree Park data were included in the regression analyses but not in the ANCOVA because this site was sampled only in 2010, when only one sample of each species was collected. Unless otherwise indicated, a $p$ value of $\alpha=0.05$ was used to judge statistical significance.

\section{Results and Discussion}

Concentrations of $\mathrm{Pb}$ were typically $<30 \mathrm{ng} / \mathrm{g}$ ww in all samples of both taxa from the MR and from the BR at Irondale (Fig. 2). Conversely, concentrations were $>300 \mathrm{ng} / \mathrm{g} \mathrm{ww}$, the level that may trigger consumption advisories, in 21 of 42 samples (50\%; 14 of 21 redhorse, 7 of 21 sunfish) from the most heavily contaminated reach (Desloge to Mammoth Access) of the BR (Fig. 2). Concentrations at House Springs were generally intermediate; only one sample (sunfish) exceeded 300 ng/g ww (Fig. 2). At contaminated BR sites within and downstream of the OLB, where $\mathrm{Pb}$ concentrations were highest, fillet $\mathrm{Ca}$ explained $75 \%$ to $>99 \%$ of the total variation in fillet $\mathrm{Pb}$. Calcium explained only $18 \%-61 \%$ of the variation in samples from the MR and 3\%-9\% in samples from
Irondale, where $\mathrm{Pb}$ concentrations were lower (Fig. 2; Table 2).

The results for sunfish from Mammoth Access highlight the potential importance of Ca-normalizing fillet $\mathrm{Pb}$ concentrations. Mean Ca concentrations in Mammoth Access sunfish were $194 \mathrm{ug} / \mathrm{g}$ ww in 2010 and 689 ug/g ww in 2012. Mean $\mathrm{Pb}$ concentrations in these samples were $133 \mathrm{ng} / \mathrm{g} \mathrm{ww}$ in 2010 and $382 \mathrm{ng} / \mathrm{g}$ ww in 2012, a difference of 2.9-fold. Mean PbCa was 253 ng/g ww in 2010 and $249 \mathrm{ng} / \mathrm{g} \mathrm{ww}$ in 2012, which are nearly identical.

Although statistically significant (Table 3), fillet $\mathrm{Ca}$ differences between taxa were relatively small (geom. mean $=461 \mu \mathrm{g} / \mathrm{g} \mathrm{ww}$ for redhorse, $388 \mu \mathrm{g} / \mathrm{g} \mathrm{ww}$ for sunfish). Fillet $\mathrm{Ca}$ differences among $\mathrm{S}-\mathrm{Ys}$ were also significant, as was $\mathrm{S}-\mathrm{Y}^{*} \mathrm{~T}$ interaction (Table 3 ). The interaction indicates that the $\mathrm{Ca}$ differences were not consistent among S-Ys and between taxa (Fig. 3a), which likely reflects differing preparation techniques. Fillet $\mathrm{Pb}$ differences between taxa and among $\mathrm{S}$-Ys were also significant (Table 3). Fillet $\mathrm{Pb}$ concentrations were significantly greater at all S-Ys within and downstream of the OLB than in the MR or at Irondale (Fig. 3b). Differences among S-Ys for $[\mathrm{Pb}] /[\mathrm{Ca}]$ were also significant, as were differences between taxa and the interaction, indicating that not all of the differences among $\mathrm{S}-\mathrm{Ys}$ and between taxa were
Fig. 2 Fillet lead $(\mathrm{Pb})$ and calcium $(\mathrm{Ca})$ concentrations in redhorse and sunfish from four groups of sites on the Big, Flat, and Meramec rivers,

2005-2012. Numbered lines (1-8; lines 7 and 8 not visible) represent linear regressions developed for each group (see text and Table 2). Dashed reference line: Concentration $(300 \mathrm{ng} / \mathrm{g} \mathrm{ww})$ that may trigger consumption advisories

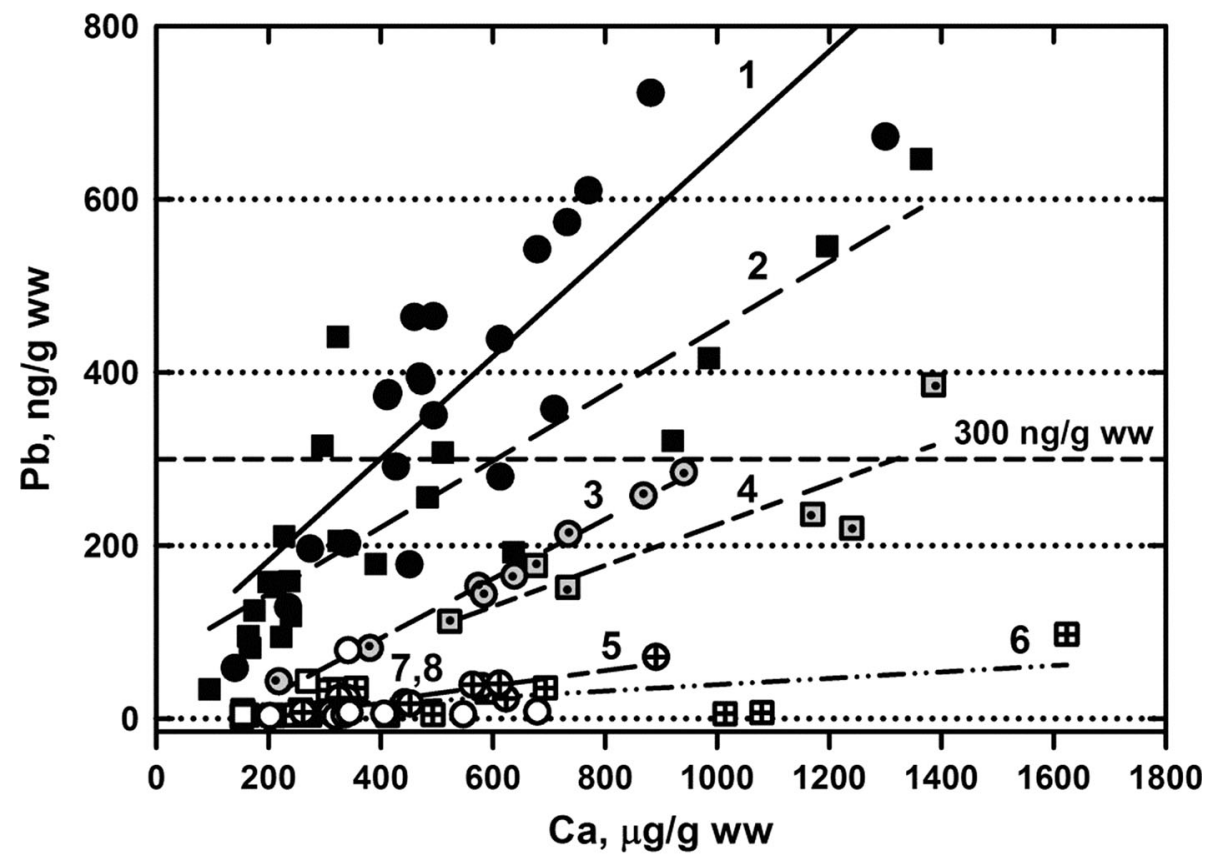

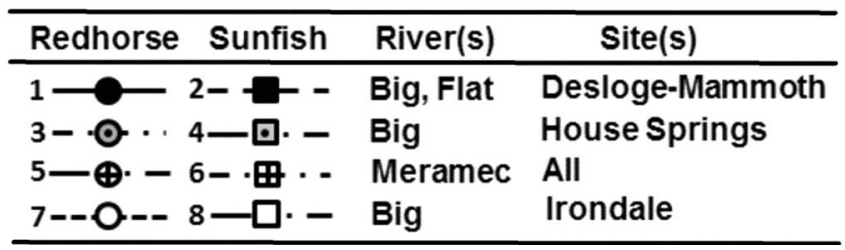


Table 2 Results of simple linear regressions between $\log _{10}$-transformed concentrations of lead and calcium in composite fillet samples of redhorse (RH) and longear sunfish (SF) from the indicated sites and groups of sites on the Big, Flat, and Meramec rivers

\begin{tabular}{llllrlllll}
\hline Group $^{\mathrm{a}}$ & River(s) & Site(s) & Taxon & $\mathrm{n}$ & \multicolumn{1}{l}{$a$} & $b$ & $r^{2}$ & \multicolumn{1}{l}{$F$} & \multicolumn{1}{l}{$p$} \\
\hline 1 & Big, Flat & Desloge-Mammoth & RH & 21 & 2.445 & 1.113 & 0.80 & 74.3 & $<0.001$ \\
2 & Big, Flat & Desloge-Mammoth & SF & 23 & 2.358 & 0.842 & 0.75 & 64.1 & $<0.001$ \\
3 & Big & House Springs & RH & 8 & 1.984 & 1.317 & $>0.99$ & 1545 & $<0.001$ \\
4 & Big & House Springs & SF & 6 & 1.969 & 0.980 & 0.84 & 21.0 & 0.010 \\
5 & Meramec & All & RH & 13 & 1.267 & 1.702 & 0.61 & 17.4 & 0.002 \\
6 & Meramec & All & SF & 15 & 1.117 & 0.026 & 0.02 & 2.95 & 0.110 \\
7 & Big & Irondale & RH & 8 & 0.834 & 0.513 & 0.03 & 0.18 & 0.685 \\
8 & Big & Irondale & SF & 8 & 0.927 & 0.743 & 0.09 & 0.56 & 0.481 \\
\hline
\end{tabular}

$n$, Number of observations; $a$, intercept; $b$, regression coefficient (slope); $r^{2}$, coefficient of determination

${ }^{a}$ Group numbers as indicated in Fig. 2

Table 3 Results of analysis-of-variance, as degrees-of-freedom $(d f)$, $F$ and $p$ values, and error mean-squares (ms) among site-years (S-Y), between fish taxa $(\mathrm{T})$, and $\mathrm{S}-\mathrm{Y}^{*} \mathrm{~T}$ interaction for $\log _{10}$ transformed

\begin{tabular}{|c|c|c|c|c|c|c|c|c|c|}
\hline \multirow[t]{2}{*}{ Source of variation } & \multirow[t]{2}{*}{$d f$} & \multicolumn{2}{|l|}{$\mathrm{Ca}$} & \multicolumn{2}{|l|}{$\mathrm{Pb}$} & \multicolumn{2}{|l|}{$\mathrm{PbCa}$} & \multicolumn{2}{|c|}{$[\mathrm{Pb}] /[\mathrm{Ca}]$} \\
\hline & & $F$ & $p$ & $F$ & $p$ & $F$ & $p$ & $F$ & $p$ \\
\hline S-Y & 14 & 5.65 & $<0.001$ & 33.6 & $<0.001$ & 53.7 & $<0.001$ & 56.0 & $<0.001$ \\
\hline $\mathrm{T}$ & 1 & 4.16 & 0.046 & 6.29 & 0.015 & 2.21 & 0.143 & 2.87 & 0.096 \\
\hline $\mathrm{S}-\mathrm{Y} * \mathrm{~T}$ & 14 & 3.31 & $<0.001$ & 1.45 & 0.160 & 1.53 & 0.133 & 2.05 & 0.029 \\
\hline Sample $e^{a, b}$ & $60^{\mathrm{b}}$ & 3.56 & 0.017 & 3.14 & 0.027 & 2.80 & 0.040 & 2.68 & 0.046 \\
\hline Error $\mathrm{ms}^{\mathrm{c}}$ & 10 & 0.035 & - & 0.290 & - & 0.049 & - & 0.047 & - \\
\hline
\end{tabular}

a Within S-Y and T

b Sample $d f=52$ for $\mathrm{PbCa}$

c Among replicate analyses

accounted for by $[\mathrm{Pb}] /[\mathrm{Ca}]$ (Table 3). Conversely, the S-Y main effect, but not $\mathrm{T}$ or $\mathrm{S}-\mathrm{Y}^{*} \mathrm{~T}$, was significant for $\mathrm{PbCa}$ (Table 3), and $\mathrm{PbCa}$ in redhorse and sunfish from all $\mathrm{BR}$ sites within and downstream of the OLB were effectively identical from 2005 through 2012 (Fig. 3c). However, differences among replicate analyses were significant for $\mathrm{Pb}, \mathrm{Ca},[\mathrm{Pb}] /[\mathrm{Ca}]$, and $\mathrm{PbCa}$ (Table 3), indicating that not all of the among-sample differences in fillet $\mathrm{Pb}$ reflect $\mathrm{Ca}$ differences. These $\mathrm{Ca}$ differences are associated with unknown factors not related to sample preparation that were not included in the statistical model. Comparisons of $\mathrm{PbCa} \mathrm{S}-\mathrm{Y}$ means nevertheless reflect temporal and geographic trends without the confounding influence of taxon or sample preparation on Ca. In addition, the normalized concentrations are in units that can be used and interpreted by natural resource managers, environmental regulators, and the public. Although results for $[\mathrm{Pb}] /[\mathrm{Ca}]$ were similar, the molar ratios are not directly useful. Moreover, because the relations between $\mathrm{Pb}$ and $\mathrm{Ca}$ are not isometric, normalization using ratios may yield counterintuitive results (Hebert and Keenleyside 1995).

As expected given that they are computed from the same values, $\mathrm{PbCa}$ and $[\mathrm{Pb}] /[\mathrm{Ca}]$ were closely correlated. The calcium $(\mathrm{Ca})$, lead $(\mathrm{Pb})$, and Ca-normalized $\mathrm{Pb}(\mathrm{PbCa})$ concentrations and $\mathrm{Pb}: \mathrm{Ca}$ molar ratios $([\mathrm{Pb}] /[\mathrm{Ca}])$ in composite fillet samples relation between $\mathrm{PbCa}$ and $[\mathrm{Pb}] /[\mathrm{Ca}]$ was statistically significant $(p<0.001)$ and explained $>98 \%$ of the variation in $\mathrm{PbCa}$ (Fig. 4). Nearly all the predicted $\mathrm{PbCa}$ concentrations (and all predicted values $>300 \mathrm{ng} / \mathrm{g} \mathrm{ww}$ ) were within the $95 \%$ prediction region of the regression, and differences between redhorse and sunfish were minimal after $\mathrm{Ca}$ normalization (Fig. 4).

Fillet $\mathrm{Pb}$ concentrations in recently collected (2005-2012) redhorse and sunfish from the FR and the BR downstream of the OLB appear to be lower than they were historically. Arithmetic mean concentrations were typically $600-900$ in suckers (three spp.) and 300-400 ng/g ww in sunfish during the early 1980s, and concentrations $>300 \mathrm{ng} / \mathrm{g}$ ww were common in most of the BR downstream of the OLB (Schmitt et al. 1984; Czarnezki 1985; Schmitt and Finger 1987). By 1998-2000, arithmetic mean concentrations in the most contaminated reach of the BR and in the FR had declined to $190-470 \mathrm{ng} / \mathrm{g}$ ww in suckers and 100-240 ng/g ww in sunfish (Gale et al. 2004), which are similar to the geometric means for 2005-2012. However, the extent to which these differences reflect declining $\mathrm{Pb}$ concentrations is difficult to ascertain because preparation methods and sampling protocols differed among studies and $\mathrm{Ca}$ was not measured. 
Fig. 3 Geometric mean $( \pm 1$ SE) fillet concentrations of a calcium $(\mathrm{Ca})$, b lead $(\mathrm{Pb})$, and c Ca-normalized $\mathrm{Pb}(\mathrm{PbCa})$ in redhorse and sunfish from siteyears on the Big, Flat, and Meramec rivers, 2005-2012 (OLB Old Lead Belt). Site-years with the same letter(s) are not significantly different $(p<0.05)$. Dark vertical lines separate MR from BR sites. Dashed reference lines for $\mathrm{Pb}$ and $\mathrm{PbCa}$ : Concentration $(300 \mathrm{ng} / \mathrm{g} \mathrm{ww})$ that may trigger consumption advisories

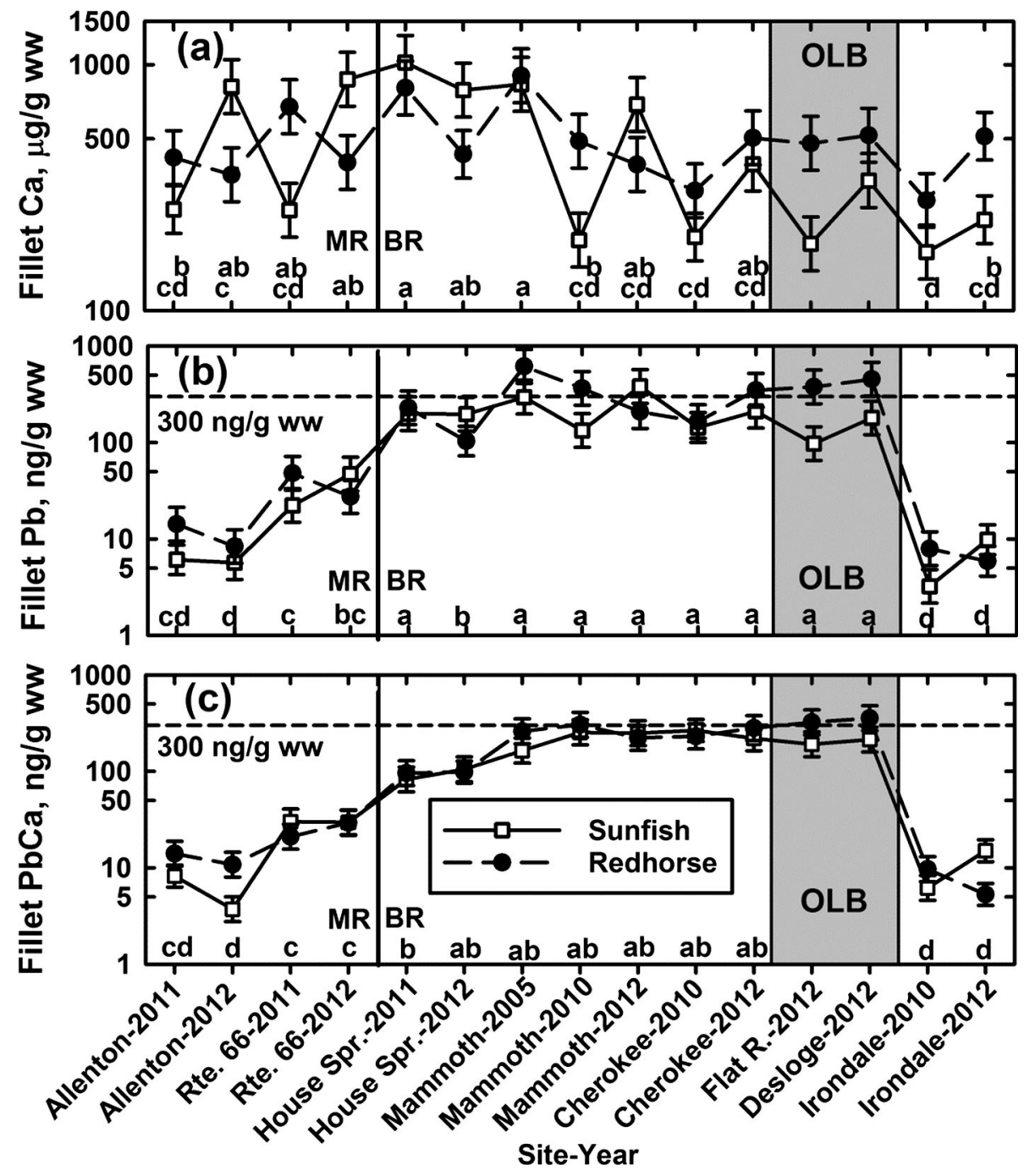

Schmitt and Finger (1987) measured fillet $\mathrm{Pb}$ and $\mathrm{Ca}$ concentrations and analyzed $[\mathrm{Pb}] /[\mathrm{Ca}]$ in redhorse collected from the BR during the early 1980s. Mean fillet $[\mathrm{Pb}] /[\mathrm{Ca}]$ was 344 in redhorse fillets from the BR at Desloge and 218-235 at two sites further downstream, which are greater than all S-Y means from the contaminated reach in 2005-2012 $(\max .=264)$. Concentrations of $\mathrm{Ca}$ and $[\mathrm{Pb}] /[\mathrm{Ca}]$ were also determined in northern hog sucker (Hypentelium nigricans) fillets obtained from the BR near Cherokee Landing in 2005; $\mathrm{Pb}$ concentrations averaged $340 \mathrm{ng} / \mathrm{g}$ ww (estimated from dw concentrations and $80 \%$ moisture) and $[\mathrm{Pb}] /[\mathrm{Ca}]$ averaged 132 (Schmitt et al. 2009), both of which are within the ranges of our 2005-2012 samples from the contaminated reach and lower than historical concentrations. Based on $[\mathrm{Pb}] /[\mathrm{Ca}]$ and its relation to $\mathrm{PbCa}$ (Fig. 4), we estimate that $\mathrm{PbCa}$ in redhorse from the most contaminated parts of the BR averaged 450-701 ng/g ww during the early 1980s (Schmitt and Finger 1987), declining to $300-500 \mathrm{ng} / \mathrm{g}$ ww in recently collected (2005-2012) redhorse and sunfish. Estimated mean $\mathrm{PbCa}$ for the northern hog suckers analyzed by Schmitt et al. (2009) was $273 \mathrm{ng} / \mathrm{g}$ ww. In addition, fillet $\mathrm{Pb}$ was $<300 \mathrm{ng} / \mathrm{g}$ ww in all redhorse from the lower BR (House Springs) in 2011 and 2012 (Fig. 2), and $\mathrm{PbCa}$ was $<300 \mathrm{ng} / \mathrm{g}$ ww in all samples of both taxa (Fig. 3c). Concentrations of $\mathrm{Pb}$ normalized to the geometric mean $\mathrm{Ca}$ concentration tend to be lower than their respective original values because the geometric mean dampens the influence of extraordinarily large values, of which there were many due to the heterogenous distribution of Ca-rich material in the samples. Depending on how the fish are prepared, $\mathrm{PbCa}$ computed from our equations may therefore underestimate the risk to human consumers. A more protective approach would be to normalize $\mathrm{Pb}$ to a higher $\mathrm{Ca}$ concentration (e.g., the 90th percentile Ca concentration), which could be easily accomplished from the information presented here.

Collectively, our results confirm previous findings that concentrations of $\mathrm{Pb}$ and $\mathrm{Ca}$ are correlated and that both are 


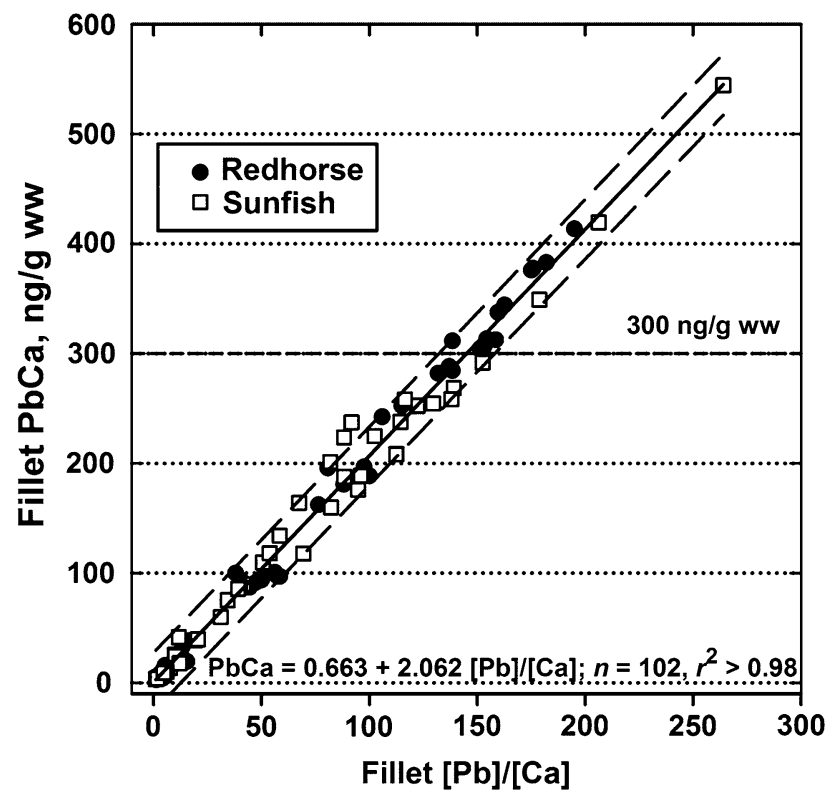

Fig. 4 Calcium $(\mathrm{Ca})$-normalized lead $(\mathrm{Pb})$ concentrations $(\mathrm{PbCa})$ versus the molar ratio of $\mathrm{Pb}$ to $\mathrm{Ca}([\mathrm{Pb}] /[\mathrm{Ca}])$ in redhorse and sunfish fillets (regression $\pm 95 \%$ prediction region). Dashed reference line: Concentration (300 ng/g ww) that may trigger consumption advisories

heterogeneously distributed. As reported for suckers (Schmitt and Finger 1987; Schmitt et al. 2007), the amount of $\mathrm{Pb}$ in fillet samples from $\mathrm{Pb}$-contaminated sites depends on the amount of material other than muscle in the sample. We found this to be equally true for sunfish, which has not been previously reported. In addition, concentrations of $\mathrm{Pb}$ in redhorse and sunfish fillets were equivalent after accounting for differences in the Ca content of the samples. Nevertheless, and although Ca-normalized $\mathrm{Pb}$ concentrations are useful for monitoring, additional information is necessary if this method is used for human health risk assessment or establishing consumption advisories. Previous studies have shown that $\mathrm{Pb}$ concentrations in fish muscle, even from heavily contaminated sites, are low (Settle and Patterson 1980; Wiener 1982; Schmitt and Finger 1987; Schmitt et al. 2009). Concentrations in the parts of fish consumed by humans depend on how much material other than muscle is present, which in turn depends on how the fish are prepared. As such, measured $\mathrm{Pb}$ concentrations in our skinless, boneless fillet samples are undoubtedly lower than what is present in fish prepared in accordance with locally prevalent methods. In southern Missouri, catostomids and other "bony" species are often prepared as bone-in, skin-on fillets that are externally scored with a knife prior to deep-frying, a process that softens the bones and allows them to be eaten (Schmitt and Finger 1987). Concentrations of $\mathrm{Ca}$ and $\mathrm{Pb}$ in fillets prepared in this manner are likely to be higher than in skinless, boneless fillets. For example, the amount of $\mathrm{Ca}$ in northern hog sucker fillets was profoundly influenced by where on the fish the fillet sample was obtained, no doubt reflecting the amount of bone it included (Schmitt et al. 2009). Elsewhere, eviscerated whole fish may be steamed, boiled, or smoked (e.g., Schmitt et al. 2006), in which case Ca and $\mathrm{Pb}$ concentrations may be higher. Regardless, whether the $\mathrm{Pb}$ is on or in the fillets or the fact that it may be associated with $\mathrm{Ca}$ is largely irrelevant to the fish consumer; it is all part of the portion and should be considered.

Reducing $\mathrm{Pb}$ concentrations in $\mathrm{BR}$ fish and rescinding the consumption advisory are goals of ongoing and future remediation in the OLB. The 2005-2012 data represent a useful benchmark against which to gauge improvement. Accurate assessment of progress based on the present monitoring design ( 3 composite samples of each taxon per site visit) will require control of variation and bias associated with $\mathrm{Ca}$ in the samples, which can be achieved via the Ca-normalization procedure described here. The procedure is reasonably straightforward, maximizes the information that can be extracted from the data, and is flexible; i.e., additional sites (as S-Ys) can be added without compromising the design and individual or multiple S-Ys can be compared as linear contrasts. In addition, statistical relations between $\mathrm{Pb}$ and $\mathrm{Ca}$ will become better defined as additional data are acquired under the consistent field protocol implemented in 2005. And finally, in-stream sediment is likely to be a focus of environmental remediation in the BR watershed. Future studies might therefore seek to establish relations between fillet $\mathrm{PbCa}$ and sediment $\mathrm{Pb}$ concentrations to focus and guide remediation.

Acknowledgments This investigation was jointly supported by the Missouri Department of Conservation (MDC) and the U.S. Geological Survey (USGS). The authors report no conflicts of interest, and appreciate the efforts of the MDC biologists who collected the samples (especially M. Reed and K. Meneau); T. May, W. Brumbaugh, M. Walther, and J. Arms (USGS) for analyzing the samples; J. Davis and J. Ross (San Francisco Estuary Institute) and S. Gao (MDC) for statistical advice; M. Struckhoff (USGS) for preparing the map and metadata; and J.E. Hinck (USGS) and J. Wenzel (MDHSS) for comments on an earlier version of the paper. All laboratory and field methods were consistent with recommendations for the humane treatment of animals in research (American Fisheries Society 2004) and all applicable guidelines for the care and use of animals. Any use of trade, firm, or product names is for descriptive purposes only and does not imply endorsement by the U.S. Government.

\section{References}

American Fisheries Society, American Institute of Fishery Research Biologists, and American Society of Ichthyologists and Herpetologists (2004) Guidelines for the use of fishes in research. American Fisheries Society, Bethesda, MD, p 57

Czarnezki J (1985) Accumulation of lead in fish from Missouri streams impacted by lead mining. Bull Environ Contam Toxicol 34:736-745 
Davis JA, Ross JRM, Bezalel SN, Hunt JA, Ichikawa G, Bonnema A, Heim WA, Crane D, Swenson S, Lamerdin C (2013) Contaminants in fish from California rivers and streams, 2011. A report of the surface water ambient monitoring program (SWAMP). California State Water Resources Control Board, Sacramento, CA. http://www.waterboards.ca.gov/water_issues/programs/ swamp/docs/rivers_study/rs_rptonly.pdf

Gale N, Adams CD, Wixson BG, Loftin KA, Huang YW (2004) Lead, zinc, copper, and cadmium in fish and sediments from the Big River and Flat River Creek of Missouri's Old Lead Belt. Environ Geochem Health 26:37-49

Hebert CE, Keenleyside KA (1995) To normalize or not to normalize? Fat is the question. Environ Toxicol Chem 14:801-807

May TW, Walther MJ, Brumbaugh WG, McKee MJ (2013) Concentrations of elements in fish fillets, fish muscle plugs, and crayfish from the 2011 Missouri Department of Conservation General Contaminant Monitoring Program. U.S. Geological Survey Open-File Report 2012-1268

Missouri Department of Health and Senior Services (2016) 2016 Missouri fish advisory. A guide to eating Missouri fish. Jefferson City. http://health.mo.gov/living/environment/fishadvisory/pdf/ fishadvisory.pdf. Accessed 9 March 2016

Missouri Department of Natural Resources (2010) Total Maximum Daily Loads (TMDL) fact sheet, Big River, Flat River Creek and Shaw Branch, Jefferson, St. Francois, and Washington Counties, Missouri. Water Protection Program, Jefferson City. http://dnr. mo.gov/env/wpp/tmdl/docs/2074-2080-2168-2170-big-r-tmdl.pdf. Accessed 9 March 2016

Schmitt CJ, Finger SE (1987) The effects of sample preparation on the measured concentrations of eight elements in the edible tissues of fish contaminated by lead mining. Arch Environ Contam Toxicol 16:185-207

Schmitt CJ, Dwyer FJ, Finger SE (1984) Erythrocyte $\delta$-aminolevulinic acid dehydratase (ALA-D) activity as an indicator of $\mathrm{Pb}$ and $\mathrm{Zn}$ bioavailability in a river contaminated by mine tailings. Can J Fish Aquat Sci 41:1030-1040

Schmitt CJ, Brumbaugh WG, Linder GL, Hinck JE (2006) A screening-level assessment of lead, cadmium, and zinc in fish and crayfish from northeastern Oklahoma, USA. Environ Geochem Health 28:445-471

Schmitt CJ, Brumbaugh WG, May TW (2007) Accumulation of metals in fish from lead-zinc mining areas of southeastern Missouri, USA. Ecotoxicol Environ Saf 67:14-30

Schmitt CJ, Brumbaugh WG, May TW (2009) Concentrations of cadmium, cobalt, lead, nickel, and zinc in blood and fillets of northern hog sucker (Hypentelium nigricans) from streams contaminated by lead-zinc mining: implications for monitoring. Arch Environ Contam Toxicol 56:509-524

Settle DM, Patterson CC (1980) Lead in albacore: guide to lead pollution in Americans. Science 207:1167-1176

USEPA (2000) Guidance for assessing chemical contaminant data for use in fish advisories: volume 1, fish sampling and analysis, 3rd edn. EPA 823-R-93-002B-00-007. U.S. Environmental Protection Agency, Office of Water, Washington, D.C.

USEPA (2016a) EPA Superfund Program: Big River Mine Tailings/ St. Joe Minerals Corp., Desloge, MO. https://cumulis.epa.gov/ supercpad/cursites/csitinfo.cfm?id=0701639. Accessed 29 March 2016

USEPA (2016b) Lead at Superfund sites: Software and user's manuals. U.S. Environmental Protection Agency, Superfund Division. http://www.epa.gov/superfund/lead-superfund-sitessoftware-and-users-manuals. Accessed 09 March 2016

Varanasi U, Markey D (1978) Uptake and release of lead and cadmium in skin and mucus of coho salmon (Oncorhynchus kisutch). Comp Biochem Physiol Part C 60:187-191

Wiener J (1982) Method for detecting trace-element contamination of fish samples from handling. Environ Sci Technol 1982:90-93 